\title{
HUMAN BONES IN SALME I BOAT-GRAVE, THE ISLAND OF SAAREMAA; ESTONIA
}

\author{
Raili Allmäe \\ Department of Archaeobiology and Ancient Technology, \\ Insititute of History, Tallinn University, Estonia
}

\begin{abstract}
In the autumn of 2008 human and animal bones came to light during the cabling works in the village of Salme, on the island of Saaremaa, Estonia. Some days later a contour of an ancient boat was discovered. The ancient boat, as well as human and animal bones inside it, dates to the second half of the $7^{\text {th }}$ century or the beginning of the $8^{\text {th }}$ century. The osteological analyses of the human bone material featured the specific quality of this burial-skeletal remains of seven men, which are unknown in the boat- and ship-burials around the Baltic Sea and in the broader context of Northern Europe. The absence of bones of dogs and horses, which are very common in Scandinavian boat- and ship-burials, is also exceptional.
\end{abstract}

Key words: boat-grave, human bones, osteology, bioarchaeology.

\section{INTRODUCTION}

The burials in boats or ships were widely spread in Northern Europe (including the British Isles) at the end of the first millennium, during the Vendel Era and especially the Viking Age [25]. Human burials in boats and ships may be inhumations as well cremations. The burial customs, related to cremation and boat/ship vary a lot. For example, one form of cremation burials known from the Viking Age Birka was scattering the cremation deposits with pyre remains to the burial place. This type of cremation burials sometimes contained boat rivets, indicating that probably the boat was burned together with human remains [28]. The same kind of archaeological finds are known from Estonia. From the 
graves of Lagedi XIII, Aseri I, and Rae I cremains with numerous boatrivets have been found $[16,19]$ as for the Lagedi grave there is also a possibility that a boat with human remains was cremated at the burial place [19]. Boat graves with inhumations are so far not known from Estonia, as well as from other Baltic states. The Salme boat is the first find of the kind in Estonia. Radiocarbon dating of osteological materials and wood from the boat confirmed that the burial was one unit and dated from the second half of the $7^{\text {th }}$ century or the beginning of the $8^{\text {th }}$ century [17]. In the summer of 2010, 30 metres from the Salme I boatgrave another boat burial with inhumations was exposed [27]. The archaeological investigation of the Salme second boat-grave will continue in the summer of 2011 , therefore it is not comprehensively discussed in the present paper.

\section{MATERIAL AND METHODS}

In the autumn of 2008 human skeletons came to light during the cabling works in the Salme village, Saaremaa, Estonia (Figure 1). The construction work was suspended and archaeological rescue excavations began. Unfortunately, most of the human bones were already taken out by that time. After a week of archaeological excavations the contour of ancient boat remains was discovered and it became evident that an important discovery for Estonian archaeology had been made - an ancient boat with inhumations. The human osteological material from the Salme boat was mainly commingled when it arrived at the institute to be analysed. Fortunately a lot of photographs were taken during the excavation.

The bones were analysed as commingled ones, using the method of recurrent bone fragments. The sex of skeletons was determined according to the widely used osteologic standards [24, 33, 7, 8, 5, 22].

The age of the buried people was determined on the basis of tooth wear, the method was chosen as the best preserved diagnostic parts of skeletons were maxilla and mandible. Three different methods [24, 33, 7] were used for age determination and then most recurrent age range was counted as most probable. For estimating the severity of deposits of dental calculus and alveolar resorption the scale proposed by Brothwell [7] was used. For stature reconstruction two methods were used: Trotter \& Gleser [30] and Gerhards [9]. The placement and plausible positions 
of bodies inside the boat contour were concluded on the basis of photos taken during the archaeological works and the information derived from the bone assemblages packed as one unit was taken into account. Comparing the photos of skeletons and bones, collected as one unit, some conclusions concerning the placement and positions of the bodies in boat were possible.

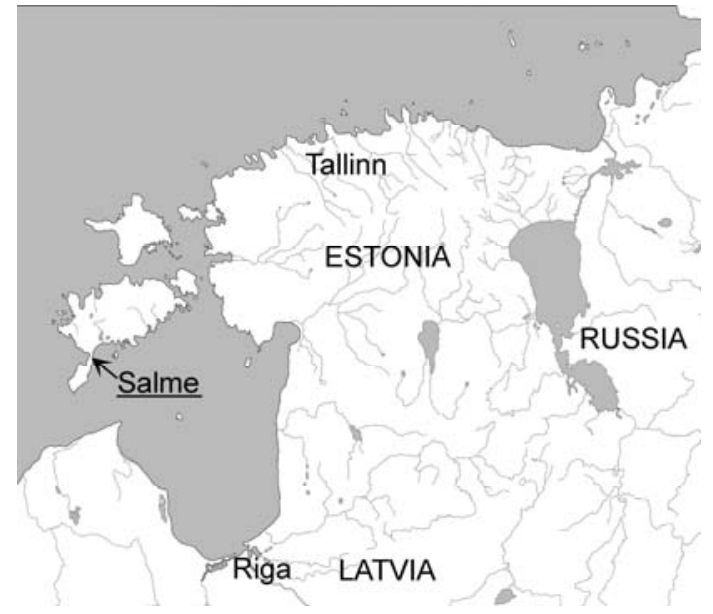

Figure 1. Location of the Salme village.

\section{RESULTS AND DISCUSSION}

\section{Analyses of commingled human bones: the minimum number of individuals, their age and sex.}

After the construction work was stopped, the preliminary analysis of the recovered human bones was conducted on site. It indicated the presence of the remains of at least five individuals. The analyses of the whole osteologial material increased the number to seven.

The excavation area was divided into three parts: the cable trench area - the disturbed area, from where most of the commingled human bones were gathered; the edge of the cable trench where presumably intact upper bodies and craniums were found, and the area around the single limestone withinin the boat contour, from where also commingled bones and some articulated bones were found. At first the mandibles and 
maxillas were paired. The loose teeth were put in right positions and the pair of the upper and the lower jaw was determined according to the congruity of occlusal surfaces of upper and lower teeth. It became evident that there were well-preserved jaws of seven individuals (except one cranium, the mandible of which is lost), 4 of these were for certain related to craniums and 3 not, as the latter was discovered among the commingled bones of the disturbed area of the boat (Table 1). All the craniums were more or less broken, especially those in the higher layers of the soil. Second, the innominate bones were paired. It was possible to pair fragments of 6 innominate bones, and to determine 7 left ones (Table 1). Third, foot bones and the distal parts of tibiae were analysed the minimum number of seven people was affirmed (Table 1). Other fragments of post-cranial skeleton were less recurrent than the above presented ones, because of the overall poor preservation of the bone material.

Table 1. Analyses of commingled bones - the minimum number of individuals

\begin{tabular}{|c|c|c|c|c|c|c|c|c|}
\hline $\begin{array}{l}\text { Diagnostic parts of } \\
\text { skeletons }\end{array}$ & \multicolumn{2}{|c|}{$\begin{array}{l}\text { Number of } \\
\text { individuals }\end{array}$} & \multicolumn{2}{|c|}{$\begin{array}{c}\text { Cable } \\
\text { trench area }\end{array}$} & \multicolumn{2}{|c|}{$\begin{array}{l}\text { Around the } \\
\text { limestone }\end{array}$} & \multicolumn{2}{|c|}{$\begin{array}{l}\text { On the edge } \\
\text { of the cable } \\
\text { ditch }\end{array}$} \\
\hline \multicolumn{9}{|c|}{ Cranial part of skeleton } \\
\hline $\begin{array}{l}\text { Maxilla and } \\
\text { mandible (pair) } \\
\text { related to craniums }\end{array}$ & \multicolumn{2}{|c|}{4} & \multicolumn{2}{|c|}{-} & \multicolumn{2}{|c|}{$\begin{array}{c}1 \text { (the } \\
\text { mandible is } \\
\text { absent) }\end{array}$} & \multicolumn{2}{|c|}{3} \\
\hline $\begin{array}{l}\text { Maxilla and } \\
\text { mandible (pair) } \\
\text { without related } \\
\text { cranium }\end{array}$ & \multicolumn{2}{|c|}{3} & \multicolumn{2}{|c|}{3} & \multicolumn{2}{|c|}{-} & \multicolumn{2}{|c|}{-} \\
\hline \multicolumn{9}{|c|}{ Post-cranial skeleton } \\
\hline Side & Left & Right & Left & Right & Left & Right & Left & Right \\
\hline $\begin{array}{l}\text { Innominate } \\
\text { (fragments) }\end{array}$ & 7 & 6 & 6 & 5 & 1 & 1 & - & - \\
\hline Calcaneus & 7 & 5 & 5 & 4 & 2 & 1 & - & - \\
\hline Talus & 4 & 7 & 2 & 6 & 2 & 1 & - & - \\
\hline $\begin{array}{l}\text { Distal end of tibial } \\
\text { bone }\end{array}$ & 7 & 6 & 6 & 5 & 1 & 1 & & \\
\hline
\end{tabular}


The sex determination was carried out taking into account all the possible descriptive diagnostic traits on craniums and post-cranial skeletons. It led to the conclusion that all 7 skeletons were of male sex. The age of men was determined on the basis of tooth wear. Three different methods were used and the most recurrent age range was concluded as most plausible (Table 2 ).

Table 2. The results of age and sex determination

\begin{tabular}{|c|c|c|c|c|c|}
\hline \multirow[b]{2}{*}{$\begin{array}{l}\text { Skeleto } \\
\text { ns }\end{array}$} & \multirow[b]{2}{*}{ Sex } & \multicolumn{3}{|c|}{ Dental age in years } & \multirow{2}{*}{$\begin{array}{l}\text { Most recurrent } \\
\text { age range }\end{array}$} \\
\hline & & $\begin{array}{c}\text { Brothwell } \\
1981\end{array}$ & $\begin{array}{c}\text { Gerassimo } \\
\text { v } 1964\end{array}$ & $\begin{array}{c}\text { Miles } \\
1963\end{array}$ & \\
\hline S1 & male & $25-35$ & $30-35$ & $25-35$ & 30-35 \\
\hline $\mathrm{S} 2$ & male & $17-25$ & $18-25$ & $18-24$ & 18-25 \\
\hline S3 & male & $20-30$ & $25-35$ & $25-30$ & $25-30$ \\
\hline S4 * & male & $20-30$ & $20-30$ & $18-24$ & 20-25 \\
\hline S5 & male & $25-30$ & $25-30$ & $18-24$ & $25-30$ \\
\hline S6 & male & $35-45$ & $35-40$ & $36-38$ & $35-40$ \\
\hline S7 & male & $40-45$ & $40-50$ & $42-46$ & $40-45$ \\
\hline
\end{tabular}

* - mandible absent

\section{Pecularity of dental and alveolar pathologies}

Dental and alveolar pathologies were also recorded and are presented in Table 3. It is noteworthy that only one case of dental caries was found, but regardless of the age of men the periapical abcess, alveolar resorption (periodontal disease) and new bone formation in alveolar sockets were quite common amongst them. These pathologies refer to the periodontal disease, which could have been caused by scurvy. The men buried in the Salme boat were probably seafarers [17]; some health indicators on their skeletons suggest the possibility of scurvy. Scurvy was quite a common disease in prehistoric times, but quite difficult to diagnose in its early stages on the basis of skeletal materials. Skeletally, the evidence for scurvy consists of new bone formation, potentially anywhere on the skeleton [29]. The periodontal disease with new bone formation in maxillar orbits, jaws and tibial bones may refer to scurvy. Vitamine $\mathrm{C}$ deficiency predisposes to bleeding into skin and beneath the periosteum; most commonly the gums swell and bleed, and this leads 
Table 3. Dental and alveolar pathologies (stages after Brothwell 1981)

\begin{tabular}{|l|c|c|c|c|}
\hline $\begin{array}{l}\text { Skeleton } \\
\text { Age }\end{array}$ & $\begin{array}{c}\text { Dental } \\
\text { calculus }\end{array}$ & $\begin{array}{c}\text { Dental } \\
\text { caries }\end{array}$ & $\begin{array}{c}\text { Periapical abcess } \\
\text { periodontal abcess }\end{array}$ & $\begin{array}{c}\text { Alveolar } \\
\text { resorption }\end{array}$ \\
\hline S1 30-35 & 1 & - & $\begin{array}{c}\text { Left } \mathrm{M}^{1} / \mathrm{M}^{2} \\
\text { Left } \mathrm{M}_{1} / \mathrm{M}_{2} \\
\mathrm{I}^{1} / \mathrm{I}^{2}\end{array}$ & 1 \\
\hline S2 18-25 & 1 & Right $\mathrm{M}_{1}$ & ${\text { Left } \mathrm{M}_{2}}$ & 2 \\
\hline S3 25-30 & 1 & - & - & 2 \\
\hline S4* 20-25 & 1 & - & - & 1 \\
\hline S5 25-30 & 0 & - & - & 1 \\
\hline S6 35-40 & 1 & - & $\begin{array}{c}\text { Left } \mathrm{M}^{2} \\
\text { Right } \mathrm{M}^{2}\end{array}$ & 2 \\
\hline S7 40-45 & 1 & - & ${\text { Right } \mathrm{M}^{1} / \mathrm{M}^{2}}$ \\
\hline
\end{tabular}

* - mandible absent, I - incisor, M - molar

to the development of peridontal disease [29]. The symptoms of scurvy and its severity on skeletons vary a lot as described by different authors. Scurvy is differently expressed on adults' and subadults' skeletons, it has been also described that different parts of skeletons may have been involved with different severity [23, 21, 31]. In British (Abingdon, Poundbury) and in Peruvian skulls the porosity of the bone tissue was most prominent on the palate, the alveolar sockets of maxilla were the second most affected area in British samples, the orbital roof in the Peruvian one [23]. Scurvy was quite well expressed on the post-cranial skeletons of South-African mineworkers and surprisingly only in half of the cases the periodontal disease was evolved [31]. The scurvy was probaly present as subclinical condition in numerous inhabitants of Northern Europe in the past. The sailors had subclinical condition of scurvy before they ever got on the ship. The rapid development of the symptoms of scurvy in sailors is caused by specific environmental conditions [15]. Maat [21] for example has demonstrated that in Low Countries scurvy was of endemic nature, appearing at the end of winter and early spring. The study of skeletal remains of the $17^{\text {th }}$ century Dutch whalers confirmed the presence of scurvy amongst them, the evidence of bleeding into joints and gums was found [20]. The frequency of scurvy may arise also during wars, but is far more widespread and linked to much greater range of activities than the recent focus on voyages and wars would suggest [6]. The sailors, seafarers and soldiers 
spent long periods at sea or far from fresh food supplies. The deficiency of vitamine $\mathrm{C}$ causes the inflammation of gums and periodontal disease. Cold weather could have triggered the spreading of bacteria and inflammation into deeper layers of alveolar tissues. Finally it reached the tissues around the tooth root and chronic periapical abcess developed. This kind of abcess of the alveolar bone without the involvment of the pulp cavity suggests periodontal abcess [26]. In its early stages scurvy may affect gums - swelling, bleeding and being infectious [21]. The skeletons in the Salme boat indicated new bone formation in alveolar sockets, periodontal disease, periodontal abscesses and some pitting on cranial bones and on the palate.

\section{Some remarks on the body height of men}

There is not much information about the stature of the Middle and the Late Iron Age men in Estonia, there are reconstructions of body height based on two male skeletons from the Maidla second stone-grave of the $5^{\text {th }}-7^{\text {th }} \mathrm{cc}$ in Läänemaa; both men were quite tall according to Trotter \& Gleser formula [30]: first between 172-176 cm and the second between 175-178 cm [1]. Five humeral, one tibial and two femoral bones were measurable in the Salme osteological material. Using the stature reconstruction models, compiled by Gerhards [9] and Trotter \& Gleser [30], it became evident that the deceased men had been quite tall (Table 4), especially S1 and S3.

The men buried in the Salme boat were quite tall in the context of Saaremaa men through centuries of the second millenium, the mean stature over $175 \mathrm{~cm}$ for males has been common for Saaremaa since the second half of the $20^{\text {th }}$ century, but not in earlier times $[11,12,13]$. Unfortunately there is no data of the body height of men from the second half of the first millenium in Saaremaa. The men in the Salme boat were quite tall $-175-180 \mathrm{~cm}$, likewise few men from some $5^{\text {th }}-7^{\text {th }}$ centuries Läänemaa in Estonia. There is not much information available concerning the osteology of skeletons recovered from Scandinavian boat-graves, the reason being the poor preservation of bones. Unfortunately in many Swedish Vendel Era boat-graves with inhumations the human bones are badly preserved, sometimes totally absent, thus the number of actual human burials in a boat is often not known [4]. So far only the stature of the man buried into the boat in Scar (Orkney) has been estimated, he was also quite tall, $181 \mathrm{~cm} \mathrm{[10].}$ 
Table 4. The reconstructed body height of men in Salme boat $(\mathrm{cm})$

\begin{tabular}{|l|c|c|}
\hline $\begin{array}{l}\text { Method } \\
\text { Bone }\end{array}$ & Gerhards (2000) & $\begin{array}{c}\text { Trotter \& Gleser } \\
(1952)\end{array}$ \\
\hline Humerus S1 & 179.7 & 182.9 \\
\hline Humerus S2 & 175.5 & 176.7 \\
\hline Humerus S3 & 178.5 & 181.3 \\
\hline Tibia commingled bones & 174.6 & 177.1 \\
\hline $\begin{array}{l}\text { Femur } \text { (pair) } \\
\text { commingled bones }\end{array}$ & 178.3 & 180.6 \\
\cline { 2 - 3 } & 178.3 & 180.6 \\
\hline
\end{tabular}

\section{The placement and the position of human bones in the boat.}

The placement of human bones in the boat and their body positions were not documented on site, the reconstruction of body positions is based on photos. The human remains were located mostly in the stern area of the boat. Unfortunately this part of the boat has been disturbed repeatedly in the course of earlier construction and cabling works. The photos, taken during the excavation, exposed three craniums with skeletons of upper bodies in initial positions on the edge of the cable trench.

Skeleton S1 - a male at the age of 30-35 years is more facing the stern, the body has slumped to the left - like from a sitting postion, his vertebra is quite horizontal in the cervical and at the beginning of the thoracic area. The body is leaning backwards, the head has fallen towards the chest, shoulders are up - a relaxed position. On the right side of S1 frontal part of the cranium there is a burning mark. Possibly it is caused by the activities which have taken place later, maybe during various construction works, for example, due to the welding work on the site. The skeletons were not deep and the heat of a welding set may have caused charring of the bone surface. There are no other signs of burning on other bones (Figure 2). Skeleton S2 - male at the age of 18-25 years is facing the bow. The body is lying on his right side and leaning on S1 right shoulder and chest - like fallen asleep, exhausted (Figure 2). Skeleton S3 - a male at the age of 25-30 years is facing the bow again 


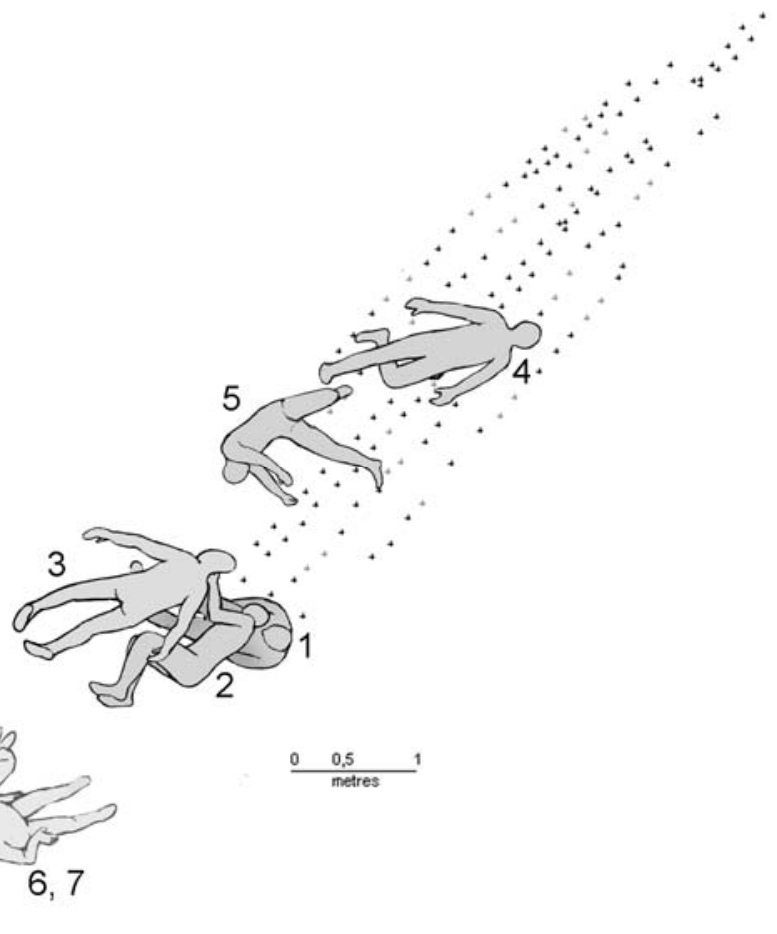

Figure 2. The placement and possible positions of bodies in the Salme boat. Drawing: Jaana Ratas. The boat contour [17], adapted.

and is lying on his face, the head leaning on the right cheek, or more obviously on the mandible; arms stretched out quite far from the body and shoulder-blades moved towards each other. The problem concerning postures of skeletons S1, S2 and S3 is that the lower parts of skeletons were destroyed and the directions of vertebras and the positions of lower extremities were not observable. The above-mentioned information could have been crucial to understand the initial positions of the bodies (Figure 2). Skeleton S4 - the position of a man at the age of 18-25 years is more dubious. Next to the limestone (in the middle of the boat) was a cranium (mandible was not found) and partly on the limestone the left innominate bone articulated with the proximal part of the femoral bone was found. Some fragments of fibula and tibia also seem to be in the initial places, these could also be related to S4 (Figure 2). It is 
noteworhy that beside the innominate bone one of the gaming pieces was found, which could have been in the pocket or in the hand of S4. The S4 body was lying more on the left side, the position also may refer to the sitting position as initial. Unfortunately, there is no firm evidence to argue that the sitting position of corpses was a part of burial ritual. On the other hand, the skeletons of Tuna-Alsike boat-graves VI, XII [2] are often found in a similar position - on one body side, with flexed knees and for these skeletons also the initial sitting position has been suggested [2]. In the Nabberör boat-grave the initial sitting position has been also supposed for two skeletons [18]. In the Valsgärde boat-grave the deceased have been placed to see the fairway [3], in the Salme boat such delibrate positioning of bodies towards one direction cannot be observed.

The position of skeleton S5 is totally fictional. The only intact part of skeleton S5 was the left foot at the edge of the cable trench and it was parallel to the ground - like a foot of a sitting, crouching or standing man. The left tibia and fibula should have been vertical to explain such a position of the foot. The leg could have been in this position, for example, due to the inner construction of the boat or things stored in the boat. When a body slumps from a sitting position, or when a corpse is recumbent, a leg cannot remain in such a position unless it is jammed between the construction elements or things (Figure 2). The paired mandible and maxilla of a male at the age of 25-30 years was found in the stern area (from the cable trench area) amongst commingled bones, the intact foot is probably related to the younger adult found mostly from the cable trench area.

The skeletons S6 - a male at the age of 35-40, and S7 - a male at the age of 40-45 were also found from the stern or the cable trench area amongst commingled bones. These men were the oldest of the seven. It is known that the older and more experienced men were responsible for steering. The placement and hypothetical body positions of men in the Salme boat are presented in Figure 2.

The Salme boat-grave is unique regarding the remarkable number of human burials inside the boat and their sex -7 burials and all male skeletons. Two boat burials with inhumations are known in Northern Europe, where the number of individuals in one boat-grave is equal or exceeds three - Nabberör in Öland and Scar in Orkney [10, 18], but in both cases individuals of different sex have been determined and in the 
Scar boat-grave amongst the others the remains of a child have been found. The Naberrör boat-grave from the Vendel Era contains four burials: the one in the centre of the boat with the remains of several artefacts has been suggested as the central or main burial, the second in bow area and other two in the stern area were less equipped [18] and have been even suggested to be the sacrifice of slaves, Anderbjörk in Hemmendorf [14]. The Viking Age boat-burial from Scar contained three burials - all buried at the same time with grave goods typical of such burials. The woman had died probably in her seventies, the man in thirties and the child around 10 years of age [10]. In the summer of 2010 the second boat-grave was discovered in the Salme village. Twentyeight human skeletons have been found in the second boat-grave of Salme so far. We hope that further archaeological investigation on the site will provide us additional data to enlighten these mysterious objects and the events of the $7^{\text {th }}-8^{\text {th }}$ centuries in the Salme village, the Island of Saaremaa.

\section{ACKNOWLEDGEMENT}

The study was undertaken in the framework of the target funded research project of the Estonian Government (SF0130012s08) and supported by the research grants from the Estonian Science Foundation ( $\mathrm{N}^{\mathrm{o}} 6899$ and 7880).

\section{REFERENCES}

1. Allmäe, R. (2003). Läänema 5.-13. sajandi kalmete antropoloogiline aines. In Mandel, M. Läänemaa 5.-13. sajandi kalmed. Eesti Ajaloomuuseum: Tallinn, $243-262$.

2. Arne, T.J. (1934). Das Bootgräberfeld von Tuna in Alsike, Uppland. KVHAA. Victor Pettersons bokindustriaktiebolag: Stockholm.

3. Arwidsson, G. (1942). Valsgärde 6. Die Gräberfunde von Valsgärde I. Acta Musei Antiquitatum Septentrionalium Regiae Universitatis Upsaliensis 1. Almqvist \& Wiksells:Uppsala.

4. Arwidsson, G. (1983). Valsgärde. In Vendel period studies. Transactions of the Boat-grave symposium in Stockholm, February 2-3, 1981. Lamm JP \& Nordström HÅ. (eds.). The Museum of National Antiquities, Stockholm Studies 2. 71-82. 
5. Bass, W. (2005). Human osteology: A Laboratory and Field Manual. Missouri Archaeological Society: Missouri.

6. Brickley, M., Ives, R. (2008). The bioarchaeology of metabolic bone disease. Academic Press: Amsterdam.

7. Brothwell, D.R. (1981). Digging up Bones 3rg Edition. Oxford University Press: Oxford.

8. Buikstra, J.E., Ubelaker, D. (eds.) (1994). Standards for Data Collection from Human Skeletal Remains. Proceedings of a Seminar at the Field Museum of Natural History. Arkansas Archaeological Survey Press: Fayetteville.

9. Gerhards, G. (2000). Latvijas iedzivotaju kermena garuma izmainas pedejo divu gadu tukstošu laika. In: "Latvijas Vēsturnieki. Antropologe profesore Dr. habil. Hist. LZA goda locekle Raisa Denisova." Zarina G and Gravere R. (Eds.) Latvijas Vestures Instituta Apgads: Riga, 55-72.

10. Graham-Campbell, J., Batey, C.E. (1998). Vikings in Scotland: An Archaeological Survey. Edinburgh University Press: Edinburgh.

11. Heapost, L., Thetloff, M. (1999). Eesti läänesaarte meeste kehamõõtude ajalised muutused. Eesti Antropomeetriaregistri aastaraamat 1999, 4853.

12. Heapost, L. (2002). Saarlaste antropoloogiast. In Saaremaa 1, Kään H, Mardiste H, Nelis R, Pesti O (Eds.). Eesti Entsüklopeediakirjastus: Tallinn, 557-594.

13. Heapost, L. (2003). Variation of stature in Estonia from the $12^{\text {th }}$ to the $20^{\text {th }}$ centuries. Papers on Anthropology XII, 51-61.

14. Hemmendorf, O. (1984). Människooffer. Et inslag i järnalderns gravritualer, belyst av et fynd i Bollstänas, Uppland. (A late Iron Age cremation burial with human sacrifice). Forvännen 79, 4-12.

15. Holck, P. (1984). Scurvy - a paleopathological problem. In: Cockburn E, ed. Papers on paleopathology. Sienna: Fifth European Members Meeting, $163-171$.

16. Jaanits, L., Laul, S, Lõugas, V., Tõnisson, E. (1982). Eesti Esiajalugu. Valgus: Tallinn.

17. Konsa, M., Allmäe, R., Maldre, L., Vassiljev, J. (2009). Rescue excavations of a Vendel Era boat-grave in Salme, Saaremaa. Archaeological Fieldworks in Estonia 2008, 53-64.

18. Lamm, J.P. (2002). Nabberör. - Reallexikon der germanischen Altertumskunde. Herausgegeben von H. Beck, D. Geuenich, H. Steuer. Begründet von J. Hoops. Zweite Auflage. Band 20. De Gruyter, 478479. 
19. Lang V. (2007). Baltimaade pronksi- ja rauaaeg. Tartu Ülikooli Kirjastus: Tartu.

20. Maat G. (1982). Scurvy in Dutch Whalers buried at Spitsbergen. Proceedings of the $4^{\text {th }}$ European Meeting of the Palaeopathology Association, Utrecht: 140-148.

21. Maat G. (2004). Scurvy in Adults and Youngsters: Dutch Experience. A Review of the History and Pathology of Disregarded Disease. International Journal of Osteoarchaeology 14: 77-81.

22. Mays, S. (2006). The Archaeology of Human Bones. London, New York.

23. Melikian, M., Waldron, T. (2003). An examination of skulls from two British sites for possible evidence of scurvy. Journal of Osteoarchaeology, 13 (4), 207-2012. DOI: 10.1002/oa.674

24. Miles, A.E.W. (1963). The Dentition in the Assessment of Individual Age in Skeletal Material. In Dental Anthropology, Brothwell DR. (ed.). Pergamon: Oxford, 191-209.

25. Müller-Wille, M. (1974). Boat-graves in northern Europe. The International Journal of Nautical Archeology and Underwater Exploration 3(2), 187-204.

26. Ortner, D.J. \& Putschar, W.G.J. (1985) Identification of pathological conditions in human skeletal remains. Smithsonian Institution Press: Washington: (Smithsonian contributions to anthropology 28).

27. Peets, J., Allmäe, R., Maldre L. (2011). Pre-Viking Age complex of burial boats in Salme village. Archaeological investigations in 2010. Archaeological Fieldwork in Estonia 2010. In print.

28. Pulsiano, P., Wolf, K. (1993). Medieval Scandinavia: an encyclopedia. Garland, 238.

29. Roberts, C., Manchester, K. (1995). The Archaeology of Disease ( $2^{\text {nd }}$ edition). Stroud: Sutton Publishing.

30. Trotter, M., Gleser, G.C. (1952). Estimation of stature from long bones of American Whites and Negroes. American Journal of Physical Anthropology 16 (1), 463-514. Ubelaker, D.H. (1978). Human Skeletal Remains Analyses, Interpretations. Chicago.

31. Van der Merwe, A.E., Steyn, M., Maat, G.J.R. (2009). Adult Scurvy in Skeletal Remains of Late $19^{\text {th }}$ Century Mineworkers in Kimberley, South Africa. International Journal of Osteoarchaeology, published online in Wiley InterScience. DOI 10.1002/oa.137.

32. WEA 1980=Recommendations (1980). Workshop of European anthropologists, "Recommendations for Age and Sex Diagnoses of Skeletons." Journal of Human Evolution 9, 517-549. 
33. Алексеев В. П., Дебец Г. Ф. (1964). Краниометрия. Методика антропологических исследований. Изд. Наука: Москва

Address for correspondence:

Raili Allmäe

Tallinn University

Institute of History

Department of Archeobiology and Ancient Technology

Rüütli 6, Tallinn 10130, Estonia

E-mail: raili.allmae@ai.ee 